\title{
The Role of NABARD in Promoting Self Help Groups (SHGs')
}

\author{
${ }^{1}$ Dr.R.S. Bharatisha Rao, ${ }^{2}$ Dr. Sreekanth. M.S. \\ ${ }^{3}$ Dr. Savitha Trivedi,
}

\begin{abstract}
The microfinance institutions started with the intention of creating financial support to the rural population, which has been neglected by many financial institutions. Micro-finance institutions have proved that rural population is bankable. The initiatives of financial intermediaries can create a dent in the development of financial credit network amongst rural population. NABARD, a major financial institution has taken a frontline in supporting the programmes of MFIs'. From the analysis it is observed that financial support provided by NABARD has reaped fruits to the rural folks.

This paper focuses on the NABARD initiates to support the rural masses through self help groups (SHGs'). This study exhibits that, though there is an increase in SHGs' year by year, it is interesting to note that there is reduction in the amount outstanding by the SHGs'. This shows beyond doubt that the rural folks are also equally positioned as far as banking operations are concerned.
\end{abstract}

Key words: NABARD, Micro finance Institutions, SHGs'.

\section{Introduction}

The primary objective of a Bank is to accelerate the pace of economic development in the country. India is a nation of villages where agriculture is the main occupation of the people. $70 \%$ of the population of the country resides in rural India depending predominantly on agriculture, cottage industries and other local, regional trades and handicrafts. The growth rate of India as per IMF projections for 2010 stands at $9.5 \%$ and the GDP growth forecast at 7.5 $\%$.( Deccan Herald, dated $9^{\text {th }}$ July, 2010). Whereas the economic condition of the people in rural India is far from satisfactory level which may be attributable for lack of adequate financial assistance.
The rural poor manage and mobilize their resources slowly over time as they lack readiness and availability of credit for enterprises and dwellings. Financial services could enable the poor to leverage their initiative, accelerating the process of building incomes, assets and economic security. The conventional financial services are hesitant to lend and serve the needs of low-income families and women-headed households. They are very often denied access to credit which in turn is attributable to practical difficulties arising from the discrepancy between the mode of operation followed by financial institutions and the economic characteristics and financing needs of low-income households.

1 Dr.R.S. Bharatisha Rao, Director, Department of Commerce and Management, SRN Adarsh College.

2 Dr. Sreekanth. M.S. Associate Professor, Bhagawan Buddha First Grade College

3 Dr. Savitha Trivedi, Assistant Professor, PG Department of Management (VTU),

Dayananda Sagar College of Engineering. 
Quite a large number of small amount of loans are the need of the hour of the rural population but the contrast is that the conventional lenders favor dealing with large loans in small numbers to minimize administration costs. They also demand collateral security which is very difficult for the poor to furnish. The tendency among the bankers is to consider low income households a bad risk imposing exceedingly high information monitoring costs on operation. Therefore, these rural poor largely depend on the local money lenders for any financial assistance. It is observed that there has been a large scale exploitation by money lenders since several decades.

Commercial banks which constitute a major segment of financial intermediaries in the country have a little contribution to the rural poor. The rural public is not completely out of the shackles of money lenders. The reasons for the situation are as follows

+ Money lenders are more accessible to rural poor than commercial banks

+ Money lenders have better knowledge of the rural population and they have understood the rural people more intimately than commercial banks

+ Money lenders could come to the rescue of the villagers at any point of distress

However, money lenders exploited the rural poor with high rates of interest, illogical terms of credit and often physical harassment which has badly affected the rural borrowers. At this point of time, commercial banks intervened in the process of rural credit only to mitigate the problem. Incidentally commercial banks realised that there were untapped rural savings which could be mobilised by effective canvassing, and initiating them to realise their future living. In addition, commercial banks have their own interest of maximizing profit which will lead them to concentrate on semi urban and rural areas.

\section{Review of Literature}

The literature available on microfinance is reviewed here with an objective to understand the conceptual background to the subject and to provide empirical research findings that have influenced the growth in this domain area of Micro Finance.

The total eradication of poverty in 1983 against the advice of banking and government officials, Professor Yunus established Grameen, a bank devoted to providing the poorest of Bangladesh with miniscule loans. His objective was not just to help the poor survive, but to create the spark of personal initiative and enterprise that would help them lift themselves out of poverty forever. It was an idea born on a day in 1976 when he loaned the equivalent of \$ 27 from his own pocket to forty two people living in a tiny village in Bangladesh. Yunus's loan helped them break the devastating cycle of poverty and changed their lives forever. His solution to the world poverty, founded on the belief that credit is fundamental human right, it is brilliantly a simple loan for poor people, which, promotes a few sound financial principles to live by, and they will help themselves.

To the extent that microfinance institutions become financially viable, self sustaining, and integral to the communities in which they operate, they have the potential to attract more resources and expand services to clients. Despite the success of microfinance institutions, only about $2 \%$ of world's roughly 500 million small entrepreneur is estimated to have access to financial services (Barry et al. 1996).

\section{Research Methodology}

\subsection{Objective of the Study}

1. To understand the status of credit facilities available to the rural population.

2. To study the NABARD initiatives in supporting the rural folks.

3. To understand the merit of SHGs' in relation to micro credit.

\subsection{Methodology}

The study is confined to the NABARD literature. The study makes use of secondary data related to microfinance. The data was collected from the 
documents published by NABARD and other related websites and published documents. For analysis, researchers have collected previous three years data from the sources mentioned above.

\section{Limitation of the Study}

1) This Study has been conducted based on data published by NABARD document for the year 2008-09

2) This study is limited to SHGs' enlisted by NABARD and cannot be generalized

\section{Micro-Finance Institutions}

Micro-finance institutions have emerged with an ambitious vision of alleviation of people living below the poverty line and to bring the poorest of the poor to the mainstream of the economy. This has paved the way for poor, especially the rural poor, to become economically independent. Micro-finance has evolved as one of the important economic development tool to support low-income group by providing financial assistance. Financial services of MFIs (Micro Finance Institutions) generally provide savings and credit facilities; however, some micro-finance institutions also provide insurance and payments services. In addition to financial intermediation, many MFIs provide social intermediation services such as group formations, creating self-confidence among the rural folks, training programmes on financial literacy and marketing skills.

MFIs vision is to outreach and bring the sustainability in the services to achieve the objective of the institution. Micro- finance programs have the potential to transform power relations and empower the poor; both men and women. In well-run micro finance programs, there is a relationship of respect between the provider and the client that is inherently empowering. As a consequence, micro- finance has become a central component of many donor agencies' and gender, poverty alleviation, and community development strategies of the national government.

Though Micro-finance emphasises on poor without categorising the gender and taking impartial stand on providing financial resources, fortunately most of the beneficiaries are women entrepreneurs. This itself creates an environment for women to become self-reliant and provide a platform for women empowerment. Although micro finance does not address all the barriers to women's empowerment, if, its programmes are properly designed, can make a vital contribution to women's empowerment.

\section{Micro -finance}

Micro-finance has taken its birth in the late seventies to help poorest of the poor. Micro- finance helps the poor to nurture their entrepreneurial skills. There by, they can improve their standards of living and can become self-sustaining to lead their life. On the one hand, for any government it is difficult to provide employment to all. On the other hand, agriculture cannot provide the fullest employment opportunities throughout the year. Agriculture is not only seasonal in India; it is heavily dependent on monsoon. Now the micro- finance has become a buzzword in almost all the developing countries. Micro-finance institutions finances in small amount to poor especially women in rural area and support them to start their own enterprise in their own villages. The finance is provided with very reasonable rate of interest and flexible

\section{The broad objectives of micro- finance are:}

1) Reduction of poverty to the bear minimum by financing for the development of skills of the rural folks

2) Providing employment opportunities to the poorest of the poor

3) Cultivating the habit of savings from the little earning of the rural masses

4) Providing credit at an affordable rate of interest

5) Disbursing the credit amount in short notice

6) Eliminating the demand for collateral security for providing credit

7) To do away with the informal money lenders from the credit link 
8) Encouraging the rural folks especially women entrepreneur

9) Supporting for a better living to the rural folks

10) Ultimately to provide better social status to the rural populace.

\section{Self help Group (SHG) Model supported by Micro Finance Institutions}

Self-help group model works with a few members ranging between a minimum of 5 and a maximum of 20 in a group; these members will have affinity to each other and have homogeneous behaviour. This group will have financial support from NGOs, commercial Banks and other financial institutions. In India, central government and many state governments are facilitating the growth of SHGs.

The typical SHG is a voluntary organization, which focuses on the development of the group members by carrying out the following activities:

1) An SHG meets regularly and addresses the problems of the group members

2) Insist the group members to make small saving in the SHGs'

3) Members in the group mutually agree to contribute to a common fund

4) Fund thus created is used for emergency needs of that group

5) Members elect the group leader on a rotation basis

6) Members take collective decisions relating to the activities of the group

7) Members solve their conflicts through mutual discussion and deliberation

8) Members provide loans without any collateral security among the members of the group

9) Some of the SHGs will enhance their activity by insuring their group members
7. The Role of National Bank for Agricultural and Rural Development (NABARD)

NABARD launched SHG-Bank Linkage Programme (SHG-BLP) in the year 1992 and has been continuously and consistently spearheading the programme in the country since then. With the growth of the program, in terms of magnitude, outreach and impact, this programme has been recognised as the largest micro finance program in the world and indeed it has become a national pride. Self Help Groups (SHGs), the delivery channel for micro credit, have demonstrated that, poverty reduction and rural women empowerment can really be achieved. Financing SHGs' has now become a favourite credit product for the financial institutions.

SHG -Bank Linkage Model has emerged in India as a core strategy for the banking system to extend their outreach to the poorest among poor. The SHG-Bank Linkage Program (SHG-BLP) within a short span of over one decade has proved beyond doubt that the poor are bankable. Micro-finance -has helped in improving their standard of living and rural empowerment, particularly of rural women. In addition to the economic development, the impact of SHG-BLP has been evident in other areas like health and sanitation, education, information dissemination etc.

As published in its report on 'micro-finance in India 2008-09' by NABARD, it claims itself to be instrumental in facilitating various activities under microfinance sector, involving all possible partners in the arena. It has been encouraging the voluntary agencies, bankers, and socially spirited individuals, other formal and informal entities and also government functionaries to promote and nurture SHGs in the country, with a social objective of uplifting the rural poor.

Model 1. Pattern of Flow of Funds to SHGs' from Financial Intermediaries. 


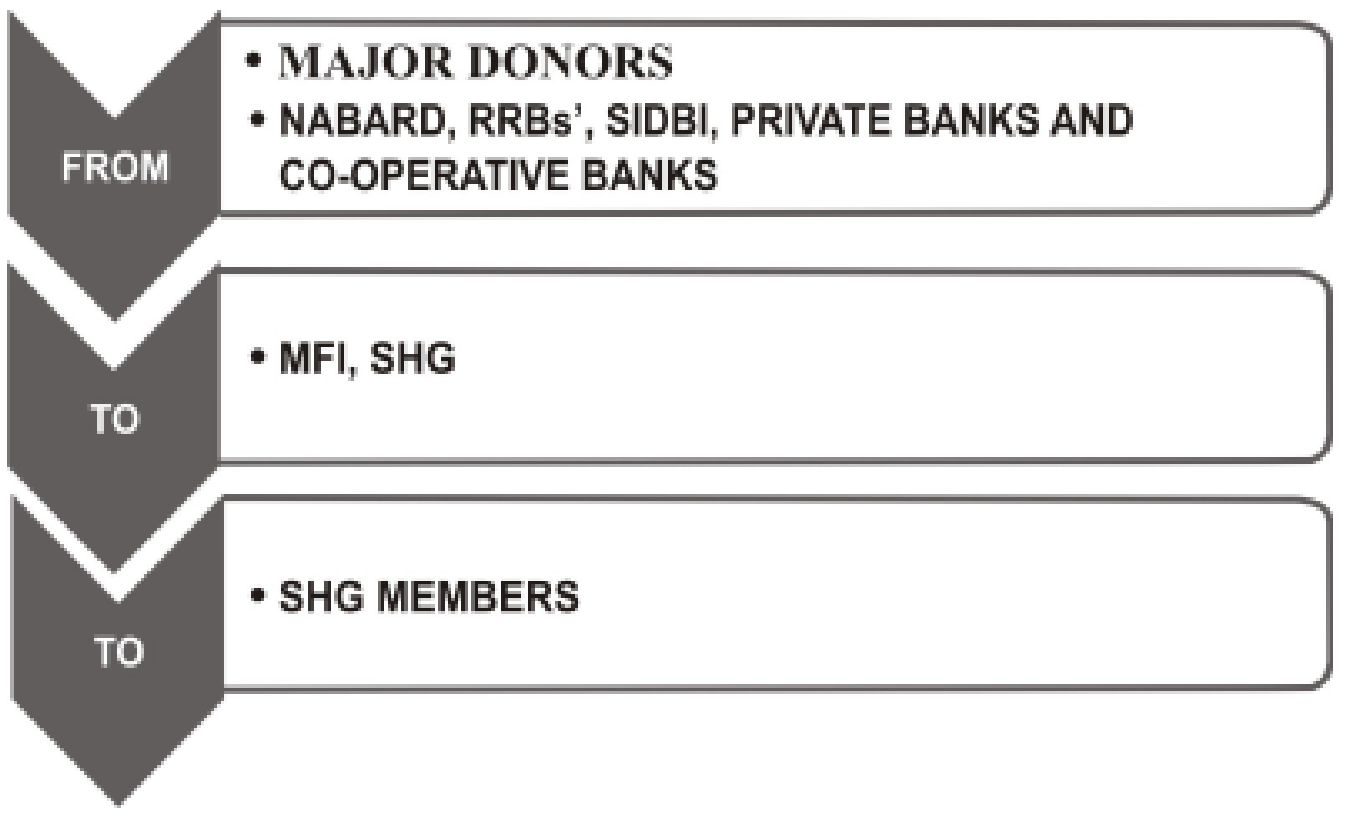

\section{Analysis of the study.}

The following table shows the progress made by the banks.

Table 1. Showing progress of micro-finance for the years 2006-07 to 2008-09.

(Rs. in crores)

\begin{tabular}{|c|c|c|c|c|c|c|c|c|c|c|}
\hline \multirow[t]{2}{*}{ Particulars } & \multicolumn{2}{|c|}{ 2006-07 } & \multicolumn{2}{|l|}{ 2007-08 } & \multicolumn{2}{|c|}{\begin{tabular}{|c} 
\% Growth \\
$(2007-2008)$
\end{tabular}} & \multicolumn{2}{|c|}{ 2008-09 } & \multicolumn{2}{|c|}{$\begin{array}{c}\% \text { Growth } \\
(2008-2009)\end{array}$} \\
\hline & $\begin{array}{l}\text { No. of } \\
\text { SHG }\end{array}$ & Amt. & $\begin{array}{l}\text { No. of } \\
\text { SHG }\end{array}$ & Amt. & $\begin{array}{c}\text { No. of } \\
\text { SHG }\end{array}$ & Amt. & $\begin{array}{l}\text { No. of } \\
\text { SHG }\end{array}$ & Amt. & $\begin{array}{c}\text { No. of } \\
\text { SHG }\end{array}$ & Amt. \\
\hline $\begin{array}{l}\text { Savings of } \\
\text { SHGs' with } \\
\text { Banks }\end{array}$ & 4160584 & 3512.71 & 5009794 & 3785.39 & 20.4 & 7.8 & 6121147 & 554562 & 22.2 & 46.5 \\
\hline $\begin{array}{l}\text { Bank loans } \\
\text { distributed to } \\
\text { SHGs' }\end{array}$ & 1105749 & 6570.39 & 1227770 & 8849.26 & 11 & 34.7 & 1609586 & 12253.51 & 31.1 & 38.5 \\
\hline $\begin{array}{l}\text { Bank Loan } \\
\text { outstanding } \\
\text { with SHGs' }\end{array}$ & 2894505 & 12366.49 & 3625941 & |16999.91 & 25.3 & 37.5 & 4224338 & 22679.84 & 16.5 & 33.5 \\
\hline
\end{tabular}

Source: NABARD Document 
in Number of SHGs' during 2007-08 and 2008-09 in \% ages.Graph Showing Growth

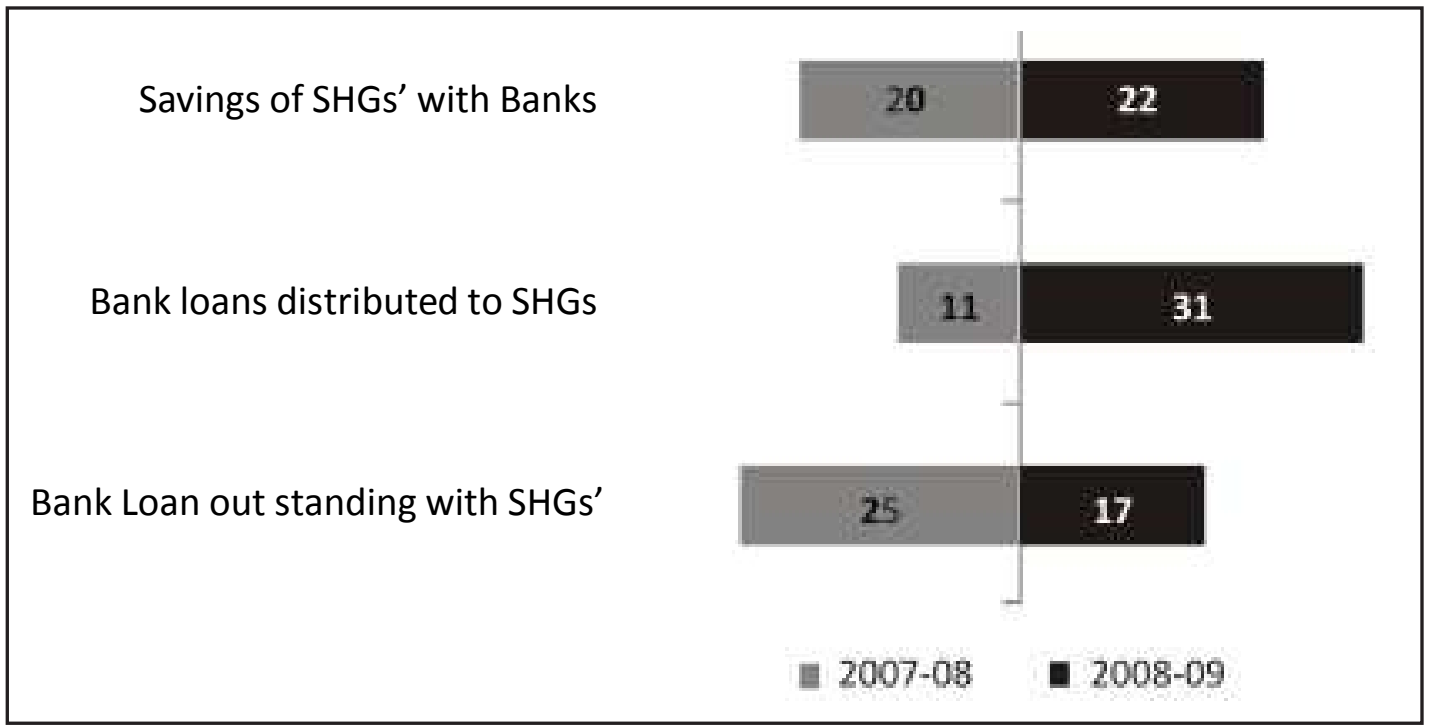

Graph showing financial performance of micro finance in \% ages during 2007-08 and 2008-09

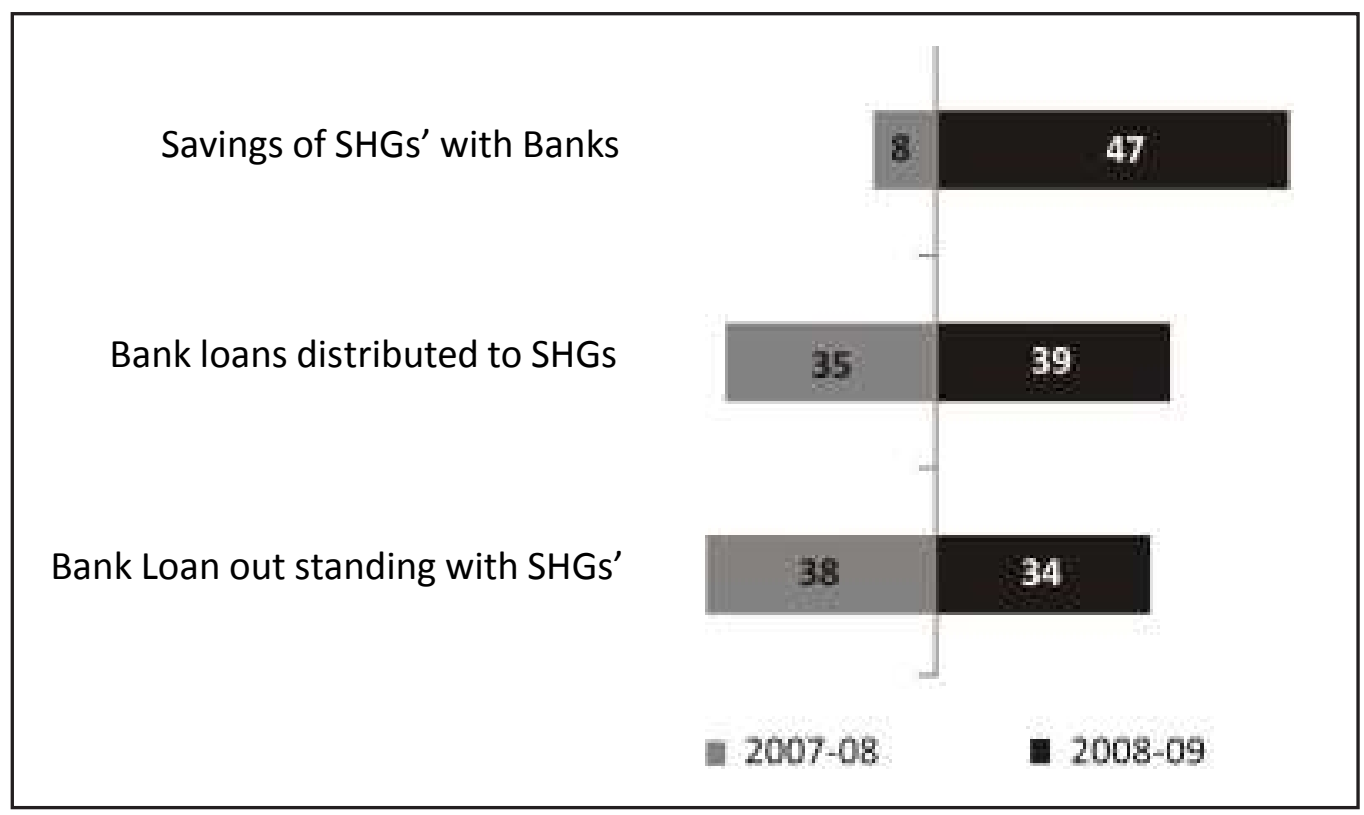

\section{Savings of SHG with banks}

From the above table analysis number of SHGs' as of 2006-07 was $41,60,584$ with a saving of Rs. 3512.71 crore with banks, during the year 2007.08 it was $50,09,794$ with saving of Rs 3785.39 crores and during 2008-09 it was in 61,21,147 with a Saving of Rs $5,54,562$ corers. This shows a marginal increase in the percentage of SHG's from $20.4 \%$ in the year 2007 to $22.2 \%$ in the year 2008 but in absolute numbers it is more than a lakh increase as compared 
to 2006 as the base year, which speaks about the awareness and the role played by the SHGs'. The amount of savings predominately increased from $7.8 \%$ to enormous $46.5 \%$. From this we can infer that the level saving from SHG's are increasing for a better cause to the rural masses.

\section{Distribution of Bank Loans}

During the year 2006-07 NABARD distributed an amount of Rs 6570.39 crores for $11,05,749$ SHG's, in the year 2007.08 an amount of Rs 8849.26corers for 12,27,770 SHG's and for the year 2008-09 an amount of Rs 12253.51 crores for 16,09,586 SHG's This shows a good increase in the percentage of number of SHG's from 11\% in the Year 2007-08 to $31.3 \%$ in the Year 2008-09. The growth in monetary values in percentages of the loan distributed for the corresponding years stood at $34.7 \%$ and $38.5 \%$. This indicates the increase in the number of banks participating and the initiative taken by them for the development of SHGs.

\section{Bank Loan outstanding with SHGs'}

During the year 2006-07, amount outstanding with SHG's Rs 12366.49 corers by $28,94,505$ SHGs', comparatively in the year 2007-08 an amount of Rs 16999.91 corers by $36,25,941$ SHG's and for the year 2008-09 an amount of Rs 22679.84 corers by $42,24,338$ SHG's. The figures for the same period in percentages shows that $25.3 \%$ and $16.5 \%$ increase in number of SHGs' and 37.5 and $33.5 \%$ in the amount of loan outstanding with SHGs'. This decrease in the percentage of number of loan outstanding with SHGs' proves that the loan provided to them are recoverable and not an impossible risk by the banks.

\section{Findings}

From the above analysis it is observed that the performance of SHGs' in terms of repayment of credit is beyond satisfactory levels. This makes a positive boost to the more number of public and private commercial banks to take a bold step and come forward in financing the rural poor for a healthy growth of the economy of the country.

\section{Conclusion}

Microfinance as a mode of credit for the rural poor is playing a signicicant role in the upliftment of the rural masses as envisaged by various programmes by the central government with the support of various financial intermediaries in general. NABARD in particular has become a major player in the promotion, training and financing of SHGs' through its huge initiatives. But the great challenges for meeting the overall and matured credit requirements of the rural population in the real sense lies in the mindset of donors and the government through a solid and concrete programmes and policies.

\section{REFERENCES}

1. Aliou Diagne -Impact of Access to Credit on Maize and Tobacco Productivity in Malawi P241

- The Triangle of Microfinance.

2. Anjini Kocuhar An Empirical Analysis of the effects if ill Health and Uncertainty on the Savings of Rural Pakistani Household P266 The Triangle of Microfinance

3. Asutosh Satpathy "Women's empowerment in India" Tech Monitor Mar-April 2008.

4. Barry, N.(1995), "The Missing Links: Financial System that Works for the Majority," Women's World Banking, New York.

5. Barry, Nancy, Armacost, Nicola and Kawas Celina (1996) "Putting Poor people's Economics at the Center of Urban Strategies," Women's World Banking, New York.

6. Bhatt, Beyond Micro Credit p 225

7. Grameen Trust (1995) Grameen Dialogue No.24, Dhaka, October.

8. Guha \& Gupta - Hand Book on Microfinance p 28

9. Mahajan \& Nagasri, Hand Book on Microfinance $p 25$

10. Malcolm Harper, Hand Book on Microfinance p 34 
11. Manohar Sharma and Gertrud Buchenrieder Impact of Microfinance on Food Security and Poverty Alleviation A Review and Synthesis of Empirical Evidence and Chapter 11 p 221.

12. Measuring the Impact of Microfinance. Taking stock of what we know small change - p 21 October 2006
13. Micro-Finance Focus August 2007 Vol-1 Issue-12.

14. Sharma $\mathrm{R} \mathrm{K}$ letters to the editor in the Daily stat September $16^{\text {th }} 2006$.

15. Small change October2006 edition SIDBI Report.

16. www.marketmix.com. 